\title{
PERBEDAAN HASIL BELAJAR PESERTA DIDIK YANG MENGGUNAKAN MODEL PEMBELAJARAN KOOPERATIF TIPE INVESTIGASI KELOMPOK (GROUP INVESTIGATION) DENGAN MODEL PEMBELAJARAN KONVENSIONAL
}

\author{
Dinda Putri Handayani ${ }^{1}$, Maman Herman², Rizka Andhika Putra ${ }^{3}$ \\ 1,2,3 Program Studi Pendidikan Akuntansi, Univesitas Galuh, Jl, RE Martadinata No. 150, Ciamis, Indonesia \\ Email: dindaputri3211@gmail.com¹, mamanhermandr@gmail.com², rizkaandhikaputra@gmail.com³
}

\begin{abstract}
Learning outcomes of students who are still low is a problem in this study, considering that learning outcomes are an important factor because it is used as one of the benchmarks for the achievement of the learning process. The learning outcomes of students who are still low are influenced by various factors including the selection of the right learning model in accordance with basic competencies. The purpose of this study was to determine: (1) Differences in student learning outcomes using the Group Investigation Type Cooperative Learning Model (Group Investigation) in the initial and final measurements in the experimental class. (2) Differences in student learning outcomes using conventional learning models in the initial measurement and final measurement in the control class. (3) The difference in learning outcomes of students who use the Cooperative Learning Model Type of Group Investigation (Group Investigation) with those using conventional learning methods in the final measurement. The research method used in this research is the experimental method with a Quasi Experimental Design Nonequivalent Control Group Design. Data collection techniques are carried out through tests, observation methods and documentation methods. The data analysis technique was carried out by testing the product moment correlation and then analyzing the correlation coefficient with validity and normality tests, followed by hypothesis testing using the $t$ test formula and $\mathrm{N}$-Gain. Based on the research results can be concluded that there is a difference in student learning outcomes in the initial measurement(pre-test)and measurement end(posttestt) in the experimental class using Cooperative Learning Model Investigation Group (Grouplnvestigation)to obtain an average increase was quite good (significant) with its $\mathrm{N}$-Gain of 0.75 , and the control class using the Conventional Learning Model by obtaining a significant (significant) increase with its $\mathrm{N}$-Gain of 0.52 in economics subjects at SMA Negeri 1 Baregbeg.
\end{abstract}

Keywords: Cooperative Learning Model Type of Group Investigation (Group Investigation) and Conventional learning model, Learning Outcomes.

\begin{abstract}
ABSTRAK
Hasil belajar peserta didik yang masih rendah merupakan masalah didalam penelitian ini, mengingat hasil belajar adalah faktor penting karena dijadikan salah satu tolak ukur pencapaian proses pembelajaran. Hasil belajar peserta didik yang masih rendah ini dipengaruhi oleh berbagai faktor diantaranya pemilihan model pembelajaran yang tepat sesuai dengan kompetensi dasar. Tujuan dari penelitian ini adalah untuk mengetahui: (1) Perbedaan hasil belajar peserta didik yang menggunakan Model Pembelajaran Kooperatif Tipe Investigasi Kelompok (Group Investigation) pada pengukuran awal dan pengukuran akhir di kelas eksperimen. (2) Perbedaan hasil belajar peserta didik yang menggunakan Model Pembelajaran Konvensional pada pengukuran awal dan pengukuran akhir di kelas kontrol. (3) Perbedaan hasil belajar peserta didik yang menggunakan Model Pembelajaran Kooperatif Tipe Investigasi Kelompok (Group Invstigation) dengan yang menggunakan Model Pembelajaran Konvensional pada pengukuran akhir. Metode penelitian yang digunakan dalam penelitian ini yaitu metode eksperimen dengan desain Quasi Eksperimental Design Nonequivalent Control Group Design. Teknik pengumpulan data yang dilakukan dengan melalui test, metode observasi dan metode dokumentasi. Teknik analisis data yang dilakukan dengan uji korelasi product moment kemudian menganalisis koefisien korelasi dengan uji validitas dan normalitas, dilanjutkan dengan uji hipotesis dengan menggunakan rumus uji $t$ dan $\mathrm{N}$-Gain. Berdasarkan hasil penelitian dapat disimpulkan bahwa terdapat perbedaan hasil belajar peserta didik pada pengukuran awal (pretest) dan pengukuran akhir (posttest) di kelas eksperimen yang menggunakan Model Pembeljaran Kooperatif Tipe Investigasi Kelompok (Group Investigation) dengan memperoleh peninkatan rata-rata yang cukup baik (signifikan) dengan $\mathrm{N}$-Gain nya sebesar 0,75 , an kelas kontrol yang menggunakan Model Pembelajaran Konvensional memperoleh peningkatan yang cukup (signifikan) dengan N-Gain nya yaitu sebesar 0,52 pada mata pelajaran ekonomi di SMA Negeri 1 Baregbeg.
\end{abstract}

Kata Kunci: Model Pembelajaran Kooperatif Tipe Investigasi Kelompok (Group Investigation), Model Pembelajaran Konvensional, Hasil Belajar.

Cara sitasi: Handayani, D. P., Herman, M., \& Putra, R. A . (2021). Perbedaan Hasil Belajar Peserta Didik yang Menggunakan Model Pembelajaran Kooperatif Tipe Investigasi Kelompok (Group Investigation) Dengan Model Konvensional. J-KIP (Jurnal Keguruan dan IImu Pendidikan), 2 (3), 131-140. 


\section{PENDAHULUAN}

Dalam Kamus Besar Bahasa Indonesia (KBBI) pendidikan berasal dari kata didik (mendidik), yaitu: memelihara dan memberi latihan (ajaran, pimpinan) mengenai akhlak dan kecerdasan pikiran. Sedangkan pendidikan mempunyai pengertian: proses pengubahan sikap dan tata laku seseorang atau kelompok orang dalam usaha mendewasakan manusia melalui upaya pengajaran dan latihan, proses perbuatan, cara mendidik. Ki Hajar Dewantara mengartikan pedidikan sebagai daya upaya untuk memajukan budi pekerti, pikiran serta jasmani anak, agar dapat memajukan kesempurnaan hidup yaitu hidup dan menghidupkan anak yang selaras dengan alam dan masyarakatnya. Dari beberapa pengertian di atas maka dapat disimpulkan bahwa pendidikan adalah upaya menuntun anak sejak lahir untuk mencapai kedewasaan jasmani dan rohani, dalam interaksi alam beserta lingkungannya. Hal ini yang menjadi cita-cita dari dan harapan masyarakat Indonesia melalui pendidikan peserta didik diharapkan akan memperoleh pengetahuan yang luas serta keterampilan yang diperlukan sebagai bekal hidup bermasyarakat, berbangsa dan bernegara. Dalam proses belajar mengajar di sekolah sangatlah penting untuk dapat meningkatkan kemampuan yang dimiliki oleh peserta didik kemampuan itu merupakan hasil belajar yang akan didapat oleh peserta didik.

Hasil belajar peserta didik yang masih rendah adalah permasalahan yang dihadapi oleh SMA Negeri 1 Baregbeg, karena pada kenyataannya tidak semua peserta didik mampu dengan cepat dalam memahami materi yang diajarkan guru saat proses belajar mengajar sedang berlangsung. Hal ini salah satu yang menyebabkan sebagian besar peserta didik terutama yang memiliki kemampuan rendah, sehingga timbulnya rasa jenuh dan bosan dalam mengikuti proses pembelajaran. Akibatnya yaitu hasil belajar peserta didik yang masih rendah. Hasil belajar menjadi sebuah pusat perhatian masyarakat hal ini dikarenakan adanya anggapan bahwa suatu aspek yang menjadi penilaian akhir dari berbagai proses yang sudah dilakukan setiap peserta didik. Hal ini sejalan dengan pendapat Sudjana (2012) yang menyatakan "Hasil belajar adalah kemampuan-kemampuan yang dimiliki peserta didik setelah menerima pengalaman belajarnya". Hasil belajar merupakan tolak ukur bagi keberhasilan proses pembelajaran yang dimanifestasikan dalam bentuk besaran angka dengan kriteria tuntas, namun pada kenyataanya masih banyak peserta didik yang belum mencapai angka Kriteria Ketuntasan Minimal (KKM).

Menurut Tari, Suwirta \& Dedeh (2020) Keberhasilan peserta didik dalam mencapai hasil belajar pada setiap peserta didik berbeda-beda. Faktor-faktor yang mempengaruhi keberhasilan peserta didik dalam mencapai hasil belajar dikelompokkan menjadi dua yaitu faktor internal dan faktor eksternal. Faktor internal adalah segala faktor yang berasal dari dalam diri peserta didik, diantaranya kepribadian, motivasi dan sebagainya. Sedangkan faktor eksternal adalah segala faktor yang berasal dari luar peserta didik, diantaranya lingkungan, keluarga, pergaulan, fasilitas belajar, dan sebagainya

Fenomena rendahnya hasil belajar menjadi alasan terkuat bagi sekolah yang ada untuk selalu meningkatkan hasil belajar, perhatian ini dapat dirasakan pada penetapan Kriteria Ketuntasan Minimal (KKM) yang harus dicapai oleh pesera didik, setiap sekolah berupaya menargetkan setiap peserta didiknya untuk mampu mencapai Kriteria Ketuntasan Minimal yang sudah ditentukan oleh sekolah. Hal ini merupakan upaya yang dilakukan sekolah dalam rangka meningkatan hasil belajar. Namun upaya dari pihak sekolah tentu saja masih belum cukup untuk meningkatkan hasil belajar, kenyataan dilapangan masih banyak peserta didik yang belum mencapai Kriteria Ketuntasan Minimal dan hal ini menunjukan bahwa masih rendah nya hasil belajar.

Sebagai data awal di bawah ini disajikan tabel 1 tentang hasil belajar siswa pada mata pelajaran Ekonomi Semester Ganjil Kelas X IPA SMA Negeri 1 Baregbeg Tahun Pelajaran 2020/2021. 
Tabel 1. Daftar Nilai Ujian Akhir Semester Ganjil Kelas X IPA SMA Negeri 1 Baregbeg

Pada Mata Pelajaran Ekonomi

\begin{tabular}{|c|c|c|c|c|c|c|c|c|c|}
\hline \multirow[b]{2}{*}{ Kelas } & \multirow[b]{2}{*}{ KKM } & \multirow[b]{2}{*}{$\begin{array}{c}\text { Jumlah } \\
\text { Peserta Didik }\end{array}$} & \multicolumn{3}{|c|}{ Nilai } & \multicolumn{4}{|c|}{ Kriteria Ketuntasan } \\
\hline & & & $\begin{array}{c}\text { Nilai } \\
\text { Tertingi }\end{array}$ & $\begin{array}{c}\text { Nilai } \\
\text { Terendah }\end{array}$ & $\begin{array}{l}\text { Rata- } \\
\text { Rata }\end{array}$ & Tuntas & $\begin{array}{c}\% \\
\text { Tuntas }\end{array}$ & $\begin{array}{l}\text { Tidak } \\
\text { Tuntas }\end{array}$ & $\begin{array}{c}\% \\
\text { Tidak Tuntas }\end{array}$ \\
\hline $\begin{array}{l}\text { X IPA } 1 \\
\text { X IPA } 2\end{array}$ & $\begin{array}{l}70 \\
70\end{array}$ & $\begin{array}{l}28 \\
28\end{array}$ & $\begin{array}{l}90 \\
80\end{array}$ & $\begin{array}{l}25 \\
50\end{array}$ & $\begin{array}{l}55,6 \\
607\end{array}$ & $\begin{array}{c}9 \\
13\end{array}$ & $\begin{array}{l}33,33 \% \\
4643 \%\end{array}$ & $\begin{array}{l}18 \\
15\end{array}$ & $\begin{array}{l}66,67 \% \\
5357 \%\end{array}$ \\
\hline
\end{tabular}

Sumber : SMA Negeri 1 Baregbeg (2021)

Tabel 1 menggambarkan bahwa nilai tertinggi yang di peroleh kelas X IPA 1 adalah 90 dan nilai terendah sebesar 25 , kesenjangan ini sangat tinggi yaitu 65 , sehingga rata-rata nilai kelas X IPA 1 mendapat nilai sebesar 55,6 dan peserta didik yang tidak tuntas atau belum mencapai Kriteria Kentuntasan Minimal berjumlah 18 orang jika dipresentasekan sebesar $66,67 \%$. Untuk kelas X IPA 2 nilai tertinggi yang di peroleh adalah 80 dan nilai terendah sebesar 50 , kesenjangan ini sangat tinggi yaitu 30, sehingga kelas X IPA 2 mendapat nilai rata-rata sebesar 60,7 dan peserta didik yang tidak tuntas atau belum mencapai Kriteria Kentuntasan Minimal berjumlah 15 orang atau jika dipresentasekan sebesar $53,57 \%$.

Berdasarkan tabel diatas, dapat diketahui bahwa nilai rata-rata mata pelajaran ekonomi di kelas X IPA SMA Negeri 1 Baregbeg tahun ajaran 2020/2021 belum semua kelas mencapai KKM (Kriteria Ketuntasan Minimal) yang ditetapkan.

Tidak maksimalnya nilai peserta didik pada mata pelajaran Ekonomi terjadi karena berbagai faktor, baik faktor eksternal maupun faktor internal. Salah satu faktor yang mempengaruhi adalah faktor eksternal yaitu ketepatan dalam memilih model pembelajaran. Upaya untuk mencapai keberhasilan dalam proses pembelajaran yaitu dengan menerapkan pedekatan pembelajaran yang artinya suatu rancangan atau kebijaksanaan dalam memulai serta melaksanakan pengajaran suatu bidang studi/mata pelajaran yang memberi arah dan corak kepada metode pengajarannya, sehingga dapat memaksimalkan perkembangan pengetahuan dan kemampuan peserta didik. Permasalahan tersebut harus segera diatasi, asumsi penulis bahwa salah satu cara untuk memperbaiki rendahya hasil belajar peserta didik adalah dengan menerapkan model pembelajaran kooperatif tipe Investigasi Kelompok (Group Investigation) dimana mengharuskan setiap peserta didik dapat menjadi lebih aktif dalam kegiatan pembelajaran. Aryansyah (2021) menyatakan bahwa "Metode mengajar yang kurang baik akan mempengaruhi belajar siswa yang tidak baik pula. Sehingga siswa kurang senang terhadap pelajaran atau gurunya, akibatnya siswa malas untuk belajar.

Pembelajaran Group Investigation sangat baik digunakan untuk mengembangkan penyelidikan penyelidikan akademik, integrasi sosial, dan proses sosial dalam belajar (Suastra, 2009). Menurut Narudin (dalam Shoimin, 2013) "group investigation merupakan salah satu bentuk model pembelajaran kooperatif yang menekankan pada partisipasi dan aktivitas siswa untuk mencari sendiri materi (informasi) pelajaran yang akan dipelajari melalui bahan-bahan yang tersedia, misalnya dari buku pelajaran atau internet". Dalam pelaksanaan model ini siswa dikelompokkan secara heterogen atas jenis kelamis, kemampuan, dan etnik 5-6 peserta didik, setiap kelompok bebas memilih subtopik dari keseluruhan unit materi (pokok bahasan) yang akan diajarakan, kemudian membuat laporan kelompok. Selanjutnya, setiap kelompok kelas mempresentasikan atau memamerkan laporannya kepada seluruh kelas, setelah setiap kelompok menyajikan hasil kerjanya di hadapan kelompok lain, guru memberikan evaluasi pembelajaran.

Berdasarkan uraian diatas penulis tertarik untuk mengadakan penelitian eksperimen di SMA Negeri 1 Baregbeg dengan judul "Perbedaan Hasil Belajar Peserta Didik Yang Menggunakan Model Pembelajaran Kooperatif Tipe Investigasi Kelompok (Group Investigation) Dengan Model Pembelajaran Konvensional Pada Mata Pelajaran Ekonomi SMA Negeri 1 Baregbeg (Studi Eksperimen Pada Kompetensi Dasar Mendeskripsikan Konsep Koperasi dan Pengelolaan Koperasi di Kelas X IPA)". 

mengetahui:

Berdasarkan uraian di atas maka tujuan yang ingin dicapai dalam penelitian ini untuk

1. Perbedaan hasil belajar peserta didik menggunakan model pembelajaran kooperatif tipe investigasi kelompok (group investigation) pada pengukuran awal (pretest) dan pengukuran akhir (posttest).

2. Perbedaan hasil belajar peserta didik menggunakan model pembelajaran konvensional pada pengukuran awal (pretest) dan pengukuran akhir (posttest).

3. Perbedaan hasil belajar peserta didik menggunakan model pembelajaran kooperatif tipe investigasi kelompok (group investigation) dengan yang menggunakan Model Pembelajaran Konvensional pada pengukuran akhir (posttest).

\section{METODE PENELITIAN}

Metode yang digunakan dalam penelitian adalah metode eksperimen. Menurut Sugiyono (2015) bahwa: "Metode penelitian eksperimen merupakan metode penelitian yang digunakan untuk mencari pengaruh treatment (perlakuan) tertentu". Tipe metode eksperimen yang digunakan dalam penelitian ini adalah Quasi Eksperimental Nonequivalent Control Group Design.

Tabel 2. Design Eksperimen

\begin{tabular}{cccc}
\hline Kelompok & Pre-test & Treatment & Post-test \\
Eksperimen & $\mathrm{O}_{1}$ & $\mathrm{X}_{1}$ & $\mathrm{O}_{2}$ \\
Kontrol & $\mathrm{O}_{3}$ & $\mathrm{X}_{2}$ & $\mathrm{O}_{4}$ \\
\hline
\end{tabular}

(Sugiyono, 2016)

Variabel dalam penelitian ini yaitu variabel independen atau variabel bebas. Untuk variabel $(X)$ adalah Model Pembelajaran Kooperatif Tipe Investiasi Kelompok (Group Investigation) pada mata pelajaran Ekonomi di Kelas X IPA 1 SMA Negeri 1 Baregbeg. Variabel dependen ini merupakan masalah yang akan dipecahkan dalam penelitian ini, sedangkan yang menjadi variabel $(Y)$ adalah hasil belajar siswa.

Populasi dalam penelitian ini adalah seluruh kelas X IPA di SMA Negeri 1 Baregbeg tahun ajaran 2020/2021 yang terdiri dari dua kelas dan berjumlah 56 orang peserta didik. Dengan siswa lakilaki berjumlah 16 orang dan siswi perempuan berjumlah 40 orang. adapun rinciannya adalah sebagai berikut:

Tabel 3. Populasi Siswa Kelas X IPA di SMA Negeri 1 Baregbeg

\begin{tabular}{cccc}
\hline \multirow{2}{*}{ Kelas } & \multicolumn{2}{c}{ Jenis Kelamin } & Jumlah \\
XI IPA 1 & 9 orang & 19 orang & 28 orang \\
XI IPA 2 & 7 orang & 21 orang & 28 orang \\
Total & 16 orang & 40 orang & 56 Orang \\
\hline
\end{tabular}

Sumber: SMA Negeri 1 Baregbeg (2021)

Karena desain penelitian menggunakan kelompok kontrol non equivalent, maka menggunakan teknik "Sampling Jenuh". Menurut Sugiyono (2015): "Sampling jenuh adalah teknik penentuan sampel bila semua anggota populasi digunakan sebagai sampel". Berdasarkan data dari populasi diatas, maka kedua kelas tersebut akan dijadikan satu kelas eksperimen dan satu kelas kontrol. Kelas X IPA 1 diberi model pembelajaran kooperatif tipe investigasi kelompok (group investigation) dan kelas X IPA 2 diberi model pembelajaran konvensional.

Data yang digunakan dalam penelitian ini yaitu data primer dan data sekunder, data primer dikumpulkan secara langsung yang berkaitan dengan obyek penelitian. Teknik yang digunakan dalam data primer yaitu dengan melaksanakan kegiatan tes hasil belajar siswa dari kegiataan pengukuran awal (pretest) dan pengukuran akhir (posttest) pada kelas eksperimen dan kelas kontrol. Sedangkan untuk data sekunder dikumpulkan dari sumber yang telah ada di SMA Negeri 1 Baregbeg. Dalam 
memperoleh data, penulis menggunakan beberapa teknik yaitu: (1)Observasi (2)Dokumentasi (3) Tes.

\section{HASIL DAN PEMBAHASAN}

Analisis data kuantitatif dalam penelitian ini digunakan untuk menjabarkan hasil penelitian dalam bentuk perhitungan angka yang mana diterapkan dengan menggunakan rumus-rumus statistik Analisis data kuantitatif yang digunakan dalam penelitian ini adalah analisis Korelasi Product Moment.

Analisis Korelasi Product Moment digunakan untuk mengetahui derajat atau kekuatan hubungan antara variabel $X$ (Model Pembelajaran Kooperatif Tipe Investigasi Kelompok (Group Investigation) dengan variabel $Y$ (Hasil Belajar Siswa).

Berdasarkan hasil penelitian, deskripsi perbedaan hasil belajar siswa yang menggunakan Model Pembelajaran Kooeratif Tipe Investigasi Kelompok (Group Investigation) pada pengukuran awal (pretest) dan pengukuran akhir (posttest), di kelas eksperimen diperoleh data sebagai berikut:

Tabel 4. Rekapitulasi Hasil Pretestdan Posttest Kelas Eksperimen

\begin{tabular}{lccc}
\hline \multicolumn{1}{c}{ Keterangan } & Pretest & Posttest & Gain \\
Jumlah Sampel & 28 & 28 & 28 \\
Nilai Tertinggi & 66,67 & 93,33 & 66,67 \\
Nilai Terendah & 20,00 & 73,33 & 20,00 \\
Nilai Rata-rata & 38,81 & 85,79 & 46,98 \\
\hline Sumber: data diolah oleh peneliti, (2021). & &
\end{tabular}

Berdasarkan tabel diatas diperoleh data pada pengukuran awal (pretest) kelas eksperimen dengan jumlah sampel 28 orang siswa, nilai tertinggi sebesar 66,67 dan nilai terendah sebesar 20,00, sedangkan untuk rata-ratanya diperoleh sebesar 38,81 . Kemudian pada pengukuran akhir (posttest) dengan jumlah sampel 28 orang siswa diperoleh nilai tertinggi sebesar 93,33 dan nilai terendah sebesar 73,33 , sedangkan untuk rata-ratanya diperoleh sebesar 85,79 . Dan untuk gain dengan jumlah sampel 28 orang siswa, nilai gain tertinggi 66,67 dan nilai terendahnya 20,00 , sedangkan nilai rata-ratanya 46,98. Berdasarkan hasil penelitian, deskripsi perbedaan hasil belajar siswa yang menggunakan Model Pembelajaran Kooeratif Tipe Investigasi Kelompok (Group Investigation) pada pengukuran awal (pretest) dan pengukuran akhir (posttest), di kelas kontrol diperoleh data sebagai berikut:

Tabel 5. Rekapitulasi Hasil Pretest dan Posttest Kelas Kontrol

\begin{tabular}{lccc}
\hline Keterangan & Pretest & Posttest & Gain \\
Jumlah sampel & 28 & 28 & 28 \\
Nilaitertinggi & 66,67 & 86,67 & 53,34 \\
Nilai terendah & 13,33 & 53,33 & 13,34 \\
Nilai rata-rata & 37,86 & 70,72 & 32,86 \\
\hline
\end{tabular}

Sumber: data diolah oleh peneliti, (2021).

Berdasarkan tabel, diperoleh data pada pengukuran awal (pretest) kelas kontrol dengan jumlah sampel 28 orang siswa, nilai tertinggi sebesar 66,67 dan nilai terendah sebesar 13,33, sedangkan untuk rata-ratanya diperoleh sebesar 37,86 . Kemudian pada pengukuran akhir (posttest) dengan jumlah sampel 28 orang siswa diperoleh nilai tertinggi sebesar 86,67 dan nilai terendah sebesar 53,33 , sedangkan untuk rata-ratanya diperoleh sebesar 70,72. Dan untuk gain dengan jumlah sampel 28 orang siswa, nilai gain tertinggi 53,34 dan nilai terendahnya 13,86 , sedangkan nilai rata-ratanya 32,86 . 
Tabel 6. Rekapitulasi Hasil Perhitungan Uji Hipotesis

\begin{tabular}{cccc}
\hline Hipotesis & thitung & tabel & Hasil Analisis \\
1) & 16,96 & 1,67 & $16,69>1,67$ \\
2) & 16,19 & 1,67 & $16,19>1,67$ \\
$3)$ & 6,59 & 1,67 & $6,59>1,67$ \\
\hline
\end{tabular}

Sumber: data diolah ole peneliti (2021).

Berdasarkan tabel diatas, dapat disimpulkan bahwa thitung $>$ dari tabel, yang berarti $\mathrm{H}_{\mathrm{a}}$ diterima dan $\mathrm{H}_{0}$ ditolak artinya terdapat perbedaan hasil belajar siswa yang menggunakan Model Pembelajaran Kooperatif Tipe Investigasi Kelompok (Group Investigation) pada pengukuran awal (pretest) dan pengukuran akhir (posttest) di kelas X IPA 1 di SMA Negeri 1 Baregbeg.

\section{PEMBAHASAN}

\section{Perbedaan Hasil Belajar Siswa yang Menggunakan Model Pembelajaran Kooperatif Tipe Investigasi Kelompok (Group Investigation) pada pengukuran awal (pretest) dan pengukuran akhir (posttest) di kelas eksperimen}

Model pembelajaran kooperatif tipe investigasi kelompok merupakan salah satu model pembelajaran yang mampu membuat siswa lebih aktif dalam proses pembelajaran, hal ini sejalan dengan pendapat Narudin (dalam Shoimin, 2013) "group investigation merupakan salah satu bentuk model pembelajaran kooperatif yang menekankan pada partisipasi dan aktivitas siswa untuk mencari sendiri materi (informasi) pelajaran yang akan dipelajari melalui bahan-bahan yang tersedia, misalnya dari buku pelajaran atau internet". Berdasarkan hasil perhitungan uji statistik, diketahui bahwa Model Pembelajaran Kooperatif Tipe Investigasi Kelompok (Group Investigation) pada pengukuran awal (pretest) dan pengukuran akhir (posttest) di kelas eksperimen. Perbedaan tersebut dapat dilihat dari hasil rata-rata nilai yang diperoleh kelas eksperimen dari pengukuran awal (pretest) dan pengukuran akhir (posttest).

Pada pengukuran awal (pretest) peserta didik memperoleh nilai rata-rata 38,81 dan pada pengukuran akhir (posttest) diperoleh sebesar 85,79. Dengan demikian terdapat perbedaan yang signifikan pada pengukuran awal (pretest) dan pengukuran akhir (posttest) kelas eksperimen yaitu sebesar 21,13 dan rata-rata N-Gain 0,75 berkategori tinggi. Perbedaan nilai rata-rata pengukuran awal (pretest) dan pengukuran akhir (posttest) di kelas eksperimen membuktikan bahwa pengukuran akhir (posttest) dilakukan setelah pembelajaran dengan menggunakan Model Pebelajaran Kooperatif tipe Investigasi Kelompok (Group Investigation) lebih besar.

Hasil pengujian ini sejalan dengan penelitian terdahulu yang dilakukan oleh Oktaviani (2017) yaitu Pengaruh Group Investigation Terhadap Hasil Belajar Fisika Peserta Didik Pada Pokok Bahasan Gerask Lurus yang menunjukan bahwa "pada kelas eksperimen dimana dalam proses pembelajaran dengan menggunakan Group Investigation diperoleh nilai 28,16 (tes awal/pretest) menjadi 79,16 (tes akhir/posttest)". Dengan demikian terdapat perbedaan yang signifkan pada pengukuran awal (pretest) dan pengukuran akhir (posttest) di kelas eksperimen yang menggunakan Model Pebelajaran Kooperatif tipe Investigasi Kelompok (Group Investigation).

Perbedaan nilai rata-rata pengukuran awal (pretest) dan pengukuran akhir (posttest) di kelas eksperimen membuktikan bahwa pengukuran akhir (posttest) yang dilakukan setelah pembelajaran dengan menggunakan Model Pembelajaran Kooperatif Tipe Investigasi Kelompok (Group Investigation) lebih besar. Artinya bahwa Model Pembelajaran Kooperatif Tipe Investigasi Kelompok (Group Investigation) sangat tepat digunakan pada Mata Pelajaran Ekonomi Kompetensi Mendeskripsikan Konsep Koperasi dan Pengelolaan Koperasi. Hal ini dikarenakan Model Pembelajaran Kooperatif Tipe Investigasi Kelompok (Group Investigation) menurut Menurut Kurniasih dan Berlin (dalam Nasution 2019) kelebihan dan kekurangan Model Pembelajaran Investigasi Kelompok (Group Investigatation) adalah sebagai berikut: 
1. Kelebihan model pembelajaran kooperatif Investigasi Kelompok (Group Investigation) :

a. Model pembelajaran GI (Group Investiagtion) memiliki dampak positif dalam meningkatkan motivasi belajar siswa.

b. Penerapan model ini mempunyai pengaruh positif, yaitu dapat meninkatkan motivasi belajar siswa.

c. Pembelajaran yang dilakukan membuat suasana saling bekerjasama dan berinteraksi antar siswa dalam kelompok tanpa memandang latar belakang.

d. Model ini juga melatih siswa untuk memiliki kemaampuan yang baik dalam berkomunikasi dan mengemukakan pendapatnya.

e. Memotivasi dan mendorong siswa agar aktif dalam proses belajar mulai dan tahap pertama sampai tahap akhir pembelajaran.

2. Sedangkan Kelemahan Model Pembelajaran Investigasi Kelompok (Group Investigation) :

a. Model Pembelajaran GI (Group Investigation) merupakan model pembelajaran yang kompleks dan sulit dilaksanakan dalam pemelajaran kooperatif.

b. Model ini membutuhkan waktu yang lama.

Adapun menurut Setiawan (dalam Irawan \& Ningrum, 2016) kelebihan model Cooperative Learning Tipe Group Investigation adalah sebagai berikut:

a) Secara Pribadi dalam proses belajarnya dapat bekerja secara bebas;

memberi semangat untuk berinisiatif, kreatif, dan aktif; rasa percaya diri dapat lebih meningkat; dapat belajar untuk memecahkan, menangani suatu masalah.

b) Secara sosial meningkatkan belajar bekerja sama; belajar berkomunikasi baik dengan teman sendiri maupun guru; belajar berkomunikasi yang baik secara sistematis; belajar menghargai pendapat orang lain; meningkatkan partisipasi dalam membuat suatu keputusan.

c) Secara akademis siswa terlatih untuk mempertanggung jawabkan jawaban yang diberikan; bekerja secara sistematis; mengembangkan dan melatih keterampilan; merencanakan dan mengorganisasikan pekerjaannya; mengecek kebenaran jawaban yang mereka buat; selalu berfikir tentang cara atau strategi yang digunakan sehingga didapat suatu kesimpulan yang berlaku umum.

Kekurangan model Cooperative Learning Tipe Group Investigation menurut Setiawan ( dalam Irawan \& Ningrum, 2016), yaitu:

a) Sedikitnya materi yang tersampaikan pada satu kali pertemuan.

b) Sulitnya memberikan penilaian secara personal.

c) Tidak semua topik cocok dengan model pembelajaran group investigation.

d) Diskusi kelompok biasanya berjalan kurang efektif.

e) Siswa yang tidak tuntas memahami materi prasyarat akan mengalami kesulitan saat menggunakan model ini.

Berdasarkan beberapa pendapat diatas dapat disimpulkan bahwa kelebihan dari model pembelajaran koopertaif tipe Investigasi Kelompok (Group Investigation) adalah memberikan kelebihan secara pribadi, secara sosiahl dan secara akademik yang pada intinya membawa atau memberikan dampak positif dalam memotivasi siswa untuk belajar dan berpengaruh juga terhadap peningkatan hasil belajar peserta didik. Tetapi model pembelajaran koopertaif tipe Investigasi Kelompok (Group Investigation) memiliki beberapa kekurangan yaitu susah atau kompleks untuk diterapkan dalam proses pembelajaran, sulitnya memberikan penilaian secara personal, tidak semua topik cocok dengan model pembelajaran group investigation, diskusi kelompok biasanya berjalan kurang efektif, siswa yang tidak tuntas memahami materi prasyarat akan mengalami kesulitan saat menggunakan model ini. 


\section{Perbedaan Hasil Belajar Siswa yang Menggunakan Model Pembelajaran Konvensional pada pengukuran awal (pretest) dan pengukuran akhir (posttest) di kelas Kontrol}

Berdasarkan perhitungan uji statistik, diketahui bahwa terdapat perbedaan hasil belajar peserta didik yang signifikan dengan menggunakan model pembelajaran konvensional di kelas kontrol pada pengukuran awal (pretest) dan pengukuran akhir (posttest). Hal tersebut dapat dilihat dari rata-rata nilai pada pengukuran awal (pretest) sebesar 37,86 dan pada pengukuran akhir (posttest) sebesar 70,72. Hasil tersebut menunjukan bahwa terdapat perbedaan hasil belajar peserta didik yang signifikan pada pengukuran awal (pretest) dan pengukuran akhir (posttest) yaitu sebesar 14,65 dan N-Gain 0,52 berkategori sedang.

Hasil pengujian ini sejalan dengan penelitian terdahulu, yaitu hasil penelitian yang dilakukan oleh Oktaviani (2017) tentang Pengaruh Group Investigation Terhadap Hasil Belajar Fisika Peserta Didik Pada Pokok Bahasan Gerask Lurus. Hasil penelitin yaitu kelas kontrol dimana dalam proses pembelajaran hanya menggunakan pendekataan konvensional, ceramah, tanya jawab diperoleh nilai pengukuran awal (Pretest) sebesar 25,3 dan untuk pengukuran akhir (Posttest) menjadi 69,67.

Peningkatan nilai rata-rata yang diperoleh siswa dengan menggunakan model pembelajaran konvensional belum maksimal, karena peningkatan hasil belajar peserta didik pada Kompetensi Dasar Mendeskripsikan Konsep Koperasi dan Pengelolaan Koperasi, termasuk ke dalam kategori Rendah. Hal tersebut disebabkan oleh beberapa faktor, sesuai dengan yang dikemukakan oleh Djamarah \& Zain (2014) antara lain:

1) siswa sulit dikontrol, apakah benar ia yang mengerjakan tugas atau orang lain;

2) khusus untuk tugas kelompok, tidak jarang yang aktif mengerjakan dan menyelesaikannya adalah anggota tertentu saja, sedangkan anggota lainnya tidak berpartisipasi dengan baik;

3) tidak mudah memberikan tugas sesuai dengan perbedaan individu siswa;

4) sering memberikan tugas yang monoton (tidak bervariasi) dapat menimbulkan kebosanan siswa.

Upaya untuk meningkatkan hasil belajar peserta didik yang menggunakan model pembelajaran konvensional dapat dilakukan dengan cara menyampaikan materi pembelajaran dengan cara yang menarik meskipun pembelajaran tetap berorientasi pada guru, serta memberikan kesempatan lebih kepada peserta didik untuk menanyakan materi yang belum dipahami. Selain itu, guru hendaknya memanfaatkan media belajar yang kreatif serta terus memberikan motivasi kepada peserta didik untuk terus meningkatkan kemampuan akademiknya.

\section{Perbedaan Hasil Belajar Siswa Yang Menggunakan Model Pembelajaran Kooperatif Tipe Investigasi Kelompok (Group Investigation) dengan yang Menggunakan Model Pembelajaran Konvensional Pada Pengukuran Akhir (Posttest)}

Perbedaan hasil belajar peserta didik yang menggunakan Model Pembelajaran Kooperatif Tipe Investigasi Kelompok (Group Investigation) lebih besar dibandingkan hasil belajar peserta didik yang mengunakan model pembelajaran konvensional pada pengukuran akhir (posttest). Hal tersebut tergambarkan dari hasil rata-rata nilai yang di peroleh peserta didik pada pengukuran akhir (posttest) kelas eksperimen sebesar 85,79 dengan $\mathrm{N}$-Gain sebesar 0,75 berkategori tinggi dan pengukuran akhir (posttest) di kelas kontrol sebesar 70,72 dengan N-Gain sebesar 0,52 berkategori sedang.

Hasil penelitian ini juga sejalan dengan penelitian terdahulu yang dilkukan oleh Titi Ratnawai yaitu Pengaruh Penerapan Model Pembelajaran Investigasi Kelompok terhadap kemampuan pemecahan masalah matematika. Dengan hasil penelitian "hasil pengumpulan dan penyajian data yang dilakukan diperoleh rata-rata tes kemampuan pemecahan masalah matematika pada kelas eksperimen lebih besar daripada rata-rata kelas kontrol". Dengan hasil penelitian pada kelas eksperimen diperoleh rata-rata pengukuran akhir (Posttest) 77,67 lebih besar daripada hasil belajar kelas kontrol dimana dengan rata-rata 59,35 .

Dengan demikian, nilai rata-rata pada pengukuran akhir di kelas eksperimen lebih besar dibandikan dengan nilai rata-rata di kelas kontrol. Artinya Model Pembelajaran Kooperatif Tipe 
Investigasi Kelompok (Group Investigation) lebih unggul dan dapat meningkatkan hasil belajar peserta didik dibandingkan dengan model pembelajaran konvensional.

\section{PENUTUP}

Penelitian ini dilakukan untuk mengetahui apakah Model Pembelajaran Kooperatif Tipe Investigasi Kelompok (Group Investigation) di SMA Negeri 1 Baregbeg (Studi Eksperimen Pada Kompetensi Dasar Mendeskripsikan Konsep Koperasi dan Pengelolaan Koperasi di Kelas X IPA). Berdasarkan hasil penelitian yang telah dilakukan, maka dapat disimpulkan bahwa:

1. Terdapat perbedaan hasil belajar peserta didik yang menggunakan Model Pembelajaran Kooperatif Tipe Investigasi Kelompok (Group Investigation) pada pengukuran awal (pretest) dan pengukuran akhir (posttest) di kelas eksperimen. Rata-rata nilai pretest sebesar 38,81 dan ratarata nilai posttest sebesar sebesar 85,79 dan perhitungan $\mathrm{N}$-Gain yaitu sebesar 0,75 dalam hal ini termasuk ke dalam kategori tinggi.

2. Terdapat perbedaan hasil belajar siswa yang menggunakan Model Pembelajaran Konvensional pada pengukuran awal (pretest) dan pengukuran akhir (posttest) di kelas kontrol. Rata-rata nilai pretest sebesar 37,86 dan rata-rata nilai Posttest sebesar 70,72 dan perhitungan N-Gain yaitu sebesar 0,52 dalam hal ini termasuk ke dalam kategori sedang.

3. Terdapat perbedaan peningkatan hasil belajar peserta didik yang menggunakan Model Pembelajaran Kooperatif Tipe Investigasi Kelompok (Group Investigation) dengan yang menggunakan Model Pembelajaran Konvensional pada pengukuran akhir (posttest) di kelas eksperimen dan kelas kontrol. Dimana masing-masing memiliki nilai rata-rata, untuk kelas eksperimen memiliki nilai sebesar 85,79 sementara untuk kelas kontrol memiliki nilai sebesar 70,72 .

\section{REKOMENDASI}

Berdasarkan kesimpulan dari hasil penelitian yang telah diuraikan sebelumnya maka peneliti menyaimpaikan rekomendasi sebagai berikut:

1. Sebaiknya Model Pembelajaran Kooperatif Tipe Investigasi Kelompok (Group Investigation) diterapkan pada kegiatan pembelajaran Ekonomi di SMA untuk meningkatkan hasil belajar siswa sebagai bekal dalam kompetensi dasar Mendeskripsikan Konsep Koperasi dan Pengelolaan Koperasi dan dapat digunakan oleh guru sebagai salah satu alternatif dalam pembelajaran.

2. Diperlukan penelitian lebih lanjut mengenai penerapan Model Pembelajaran Kooperatif Tipe Investigasi Kelompok (Group Investigation) supaya dapat memperkuat hasil penelitian ini terutama dalam mata pelajaran lain.

3. Bagi peneliti selanjutnya hendaknya hasil penelitian ini dapat dijadikan referensi untuk menggunakan Model Pembelajaran Kooperatif Tipe Investigasi Kelompok (Group Investigation) atau mengkombinasikan dengan model pembelajaran yang lain serta membandingkan hasil.

\section{UCAPAN TERIMAKASIH}

Dalam penyusunan skripsi ini tidak lepas dari berbagai hambatan dan kesulitan, namun atas ridha Alloh SWT. Serta dorongan, bantuan dan bimbingan dari berbagai pihak, akhirnya peneliti dapat menyelesaikan skripsi ini.

Pada kesempatan ini penulis mengucapkan terima kasih yang sebesar-besarnya kepada yang terhormat Bapak Dr. Maman Herman, M.Pd., selaku pembiming I dan Bapak Rizka Andhika Putra, S.Pd., M.M. selaku pembimbing II yang senantiasa mengarahkan dan membimbing penulis dalam penyusunan ini. selanjutnya ucapan terima kasih penulis sampaikan kepada:

1. Untuk kedua orang tua dan keluarga tercinta, Bapak Baban Syah Beni dan Ibu Laela Nurjanah, serta kakak dan adik saya (Ikbal Zabari Aziz Sultoni, Beni Rahmatulloh, S.Pd., Ferry Nur Ardiansyah, 
Mochammad Sidik Permana) yang senantiasa memberikan kasih sayangnya dan segala doa'a serta dorongan moril maupun materil yang selalu tercurah dalam setiap langkah penulis.

2. SMA Negeri 1 Baregbeg.

\section{DAFTAR PUSTAKA}

Aryansyah, F. (2021). Pelaksanaan Question Student Have Method Dalam Meningkatkan Hasil Belajar Pada Mata Pelajaran Ekonomi di SMA. J-KIP (Jurnal Keguruan dan IImu Pendidikan), 2 (1), 9198.

Depdiknas. (2003). Undang-undang Republik Indonesia Nomor 20 Tahun 2003 Tentang Sistem Pendidikan Nasional. Jakarta: Depdiknas.

Djamarah, S. B \& Zain, A. (2014). Strategi Belajar Mengajar. Jakarta:Rineka Cipta.

Irawan, F. J \& Ningrum. (2016). Pengaruh Penggunaan Model Cooperative Learning Tipe Group Investigation (GI) Terhadap Hasil Belajar Prakarya Dan Kewirausahaan (Pkwu) Siswa Kelas X Semester Genap Smk Negeri 1 Metro Tp 2015-2016. (online) Vol.4. No.2 (2016) 61-68. (https://media.neliti.com/media/publications/162284-ID-none.pdf), diakses 01 April 2021.

Nasution, A. R. (2019). Pengaruh Model Pembelajaran Kooperatif Tipe Gl (Group Investigation) Terhadap Hasil Belajar IPA di Kelas IV SD Negeri 101887 Bangun Sari Kecamatan Tanjung Morawa Kabupaten Deli Serdang. PGMI. Fakultas IImu Tarbiyah dan Keguruan. Universitas Islam Negeri Sumatera Utara.

Oktaviani, E. (2017). Pengaruh Group Investigation Terhadap Hasil Belajar Fisika Peserta Didik Pada Pokok Bahasan Gerak Lurus Kelas X Di Sman 1 Jabung Lampung Timur. Thesis, IAIN Raden Intan Lampung.

Suastra, I. W. (2009). Pembelajaran Sains Terkini. Singaraja: Universitas Pendidikan Ganesha.

Shoimin, A. (2013). 68 Model Pembelajaran Inovatif dalam kurikulum 2013. Yogyakarta: Ar-Ruzz Media.

Sudjana. (2012). Penilaian Hasil Proses Belajar Mengajar. Bandung: Remaja Rosdakarya.

Sugiyono. (2016). Metode Penelitian Pendidikan. Bandung: Alfabeta.

Sugiyono. (2015). Metode Penelitian Kombinasi (mixed methods). Bandung: Alfabeta.

Tari, H. D., Suwrta,U \& Dedeh (2020) Pengaruh Penerapan Model Pembelajaran Kooperatif Tipe Teams Games Tournament (TGT) Terhadap Hasil Belajar Peserta Didik pada Mata Pelajaran Ekonomi di MAN 2 Kota Tasikmalaya. J-KIP (Jurnal Keguruan dan IImu Pendidikan), 1 (1), 1926. 